\title{
Mesoscale and Microscale Structures of Snow Clouds over the Sea of Japan Part II: Time Change in Airflow Structures in Isolated Snow Clouds Derived from Dual-Döppler Radar Observations
}

\author{
- A Case Study - \\ By Yoshinori Yamada, Takayo Matsuo, Masataka Murakami, Hakaru Mizuno \\ Meteorological Research Institute, Tsukuba, Ibaraki 305, Japan \\ and \\ Koyuru Iwanami \\ Nagaoka Institute of Snow and Ice Studies, Nagaoka, Niigata 940, Japan \\ (Manuscript received 10 December 1993, in revised form 26 July 1994)
}

\begin{abstract}
Time change in airflow structures in isolated snow clouds over the Sea of Japan was investigated by means of dual-Döppler radar observations. Rawinsonde and dropsonde observations were also carried out to support the Döppler radar observations.

Isolated snow clouds were observed in a late stage of an outbreak of winter monsoon and had a lifetime of about 1 hour. The sonde observations showed that these clouds were formed in a convectively unstable layer with a weak vertical wind shear. The Döppler radar observations demonstrated that the airflow patterns inside the clouds varied with time. In the developing stage, updrafts dominated in the clouds with slight downdrafts. In the mature stage, updraft and downdraft were comparable in area. In the decaying stage, downdraft was dominant in the clouds. The updraft and downdraft existed in the forward and rearward portion with respect to the cloud movement, respectively. The magnitude of updrafts was at most $2 \mathrm{~m} \mathrm{~s}^{-1}$ in the developing and mature stages, and had smaller values in decaying stage.

A conceptual model of airflow structures is proposed based on the results of the observations.
\end{abstract}

\section{Introduction}

It is well known that several types of snow clouds appear over the Sea of Japan in the winter monsoon seasons. Sakakibara et al. (1988) categorized snow clouds during heavy snowfalls into several types from analyses of infrared satellite images: i.e., band cloud with the orientation parallel to the low-level wind (L-type), band cloud with the orientation perpendicular to the low-level wind (T-type), open cells, and isolated snow clouds, which exist apart from each other and not organized on the mesoscale, etc. They also showed that major types of snow clouds during heavy snowfall periods were open cells, L-type band clouds of width greater than $30 \mathrm{~km}$, and isolated snow clouds. Studies on airflow as well as microphysical structures in the various

(C) 1994, Meteorological Society of Japan types of snow clouds are important in the understanding of the precipitation mechanism. Among those snow clouds, airflow structures in the L-type and T-type snow bands have been investigated so far by some researchers over the Sea of Japan (for example, Yamada et al., 1992; Satoh et al., 1992) and over the Great Lakes in the US (for example, Kelly, 1982; Kelly, 1984; Kristovich, 1990). However, few studies have been made on isolated snow clouds in either region. Therefore, there is little knowledge of their kinematic and thermodynamical structures and environmental conditions where they develop, although Ikawa et al. (1991) numerically simulated the formation of isolated snow clouds in a weak vertical shear condition over the Sea of Japan. As for deep convection, it is well known that a weak vertical shear is favorable for the formation of isolated convective clouds (for example, Weisman and 


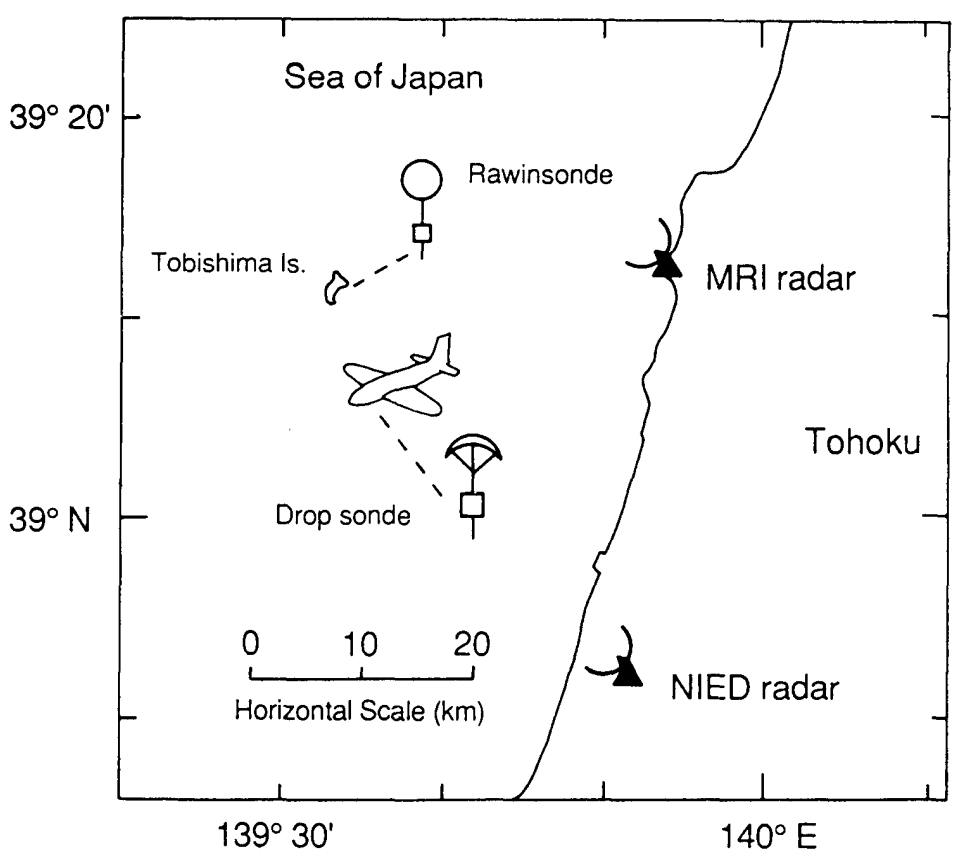

Fig. 1. Location of observations and instrumentation in 1992.

Surface

0900 JST 9 Feb. 1992

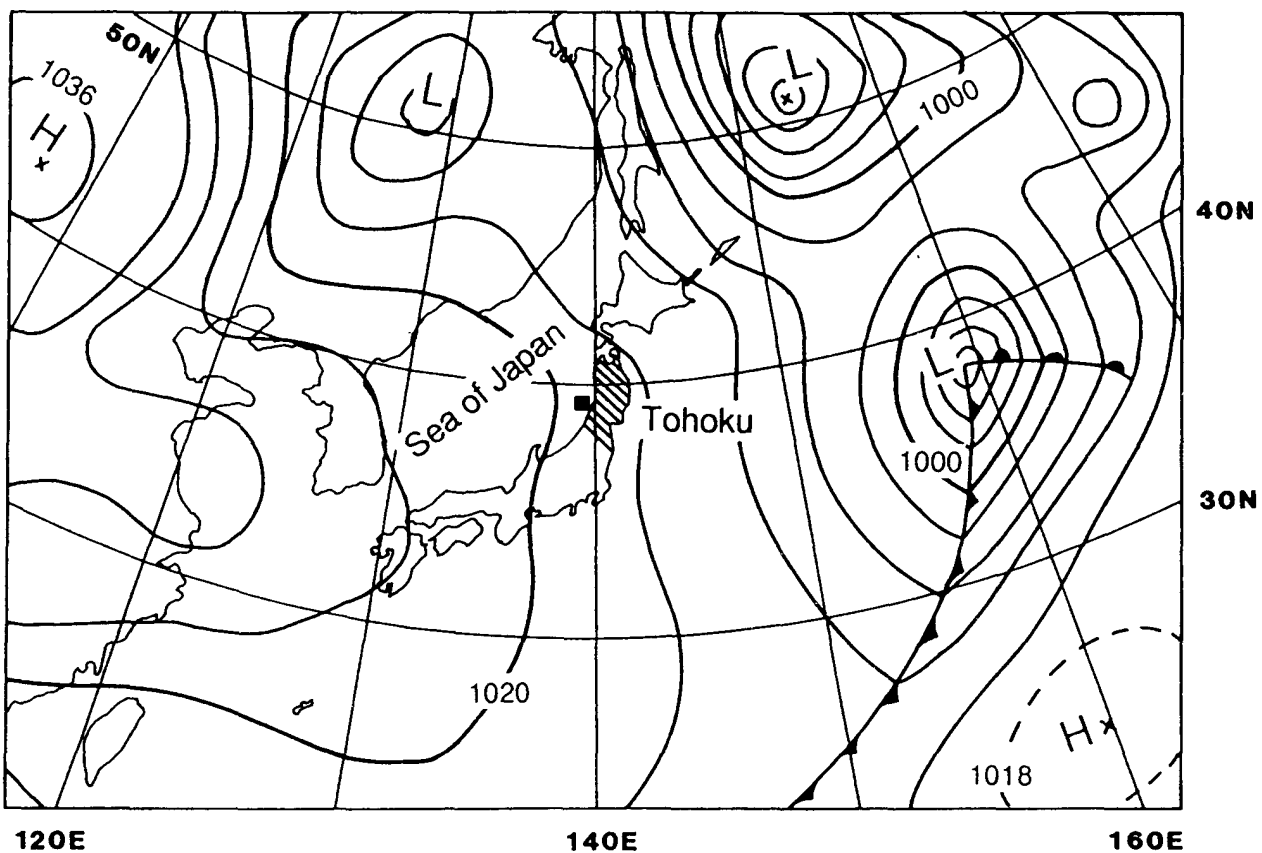

Fig. 2. Surface weather map at 0900 JST on 9 February 1992. The interval of the pressure contours is $4 \mathrm{hPa}$. The observation area is indicated by a solid square. The Tohoku District is indicated by hatching.

Klemp, 1982; Weisman and Klemp, 1984; Tabata et al., 1989). Though the isolated snow clouds brought about light snowfall in the coastal regions (Sakakibara et al., 1988), they, as well as the band clouds, should be studied because they are one of the major types of snow clouds during heavy snowfall periods and their contribution to the total snowfall amount in the coastal regions is not small.

This paper presents time changes of airflow structures in isolated snow clouds examined with dualDöppler radar observations. The isolated snow clouds were observed in the winter of 1992 , which is the fourth winter season of a five-year field project. The objectives of the project are to study precipita- 


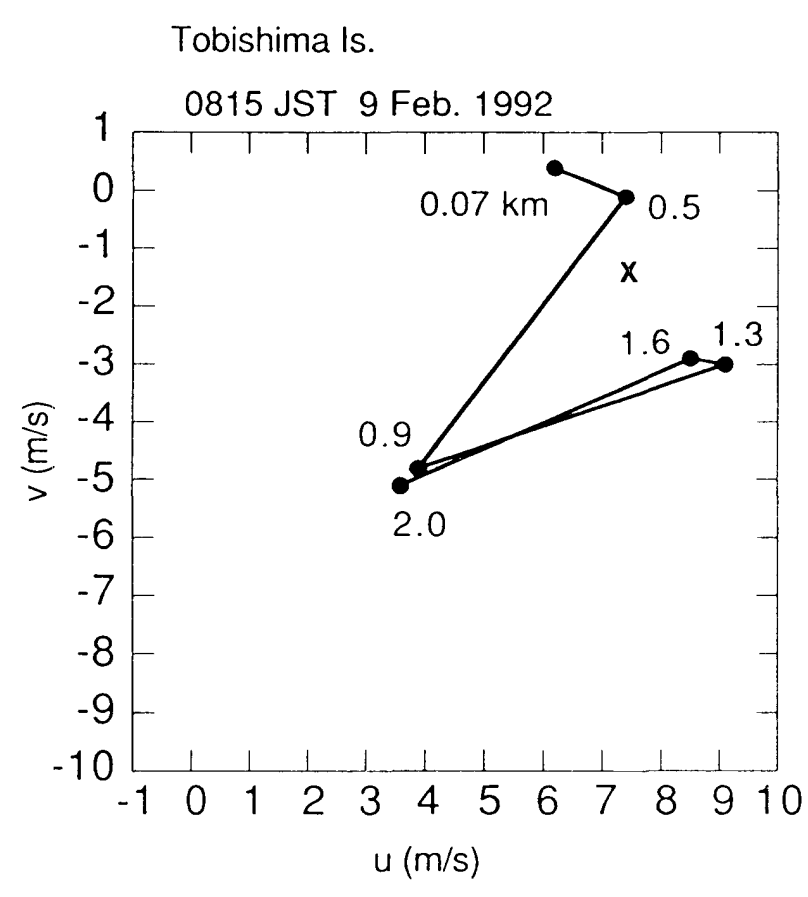

Fig. 3. Wind hodograph measured at 0815 over Tobishima Is. Solid circles indicate wind velocities at some specific levels. Numbers adjacent to the solid circles denote heights in kilometers above sea level. The movement of the clouds is also indicated by a cross mark.

tion mechanisms in the snow clouds over the Sea of Japan and to seek feasibilities for their modification by seeding. The overview of the project is presented in Murakami et al. (1994).

\section{Location of observations and the atmo- spheric condition}

The observations were carried out in a coastal region of the Tohoku District of Japan facing the Sea of Japan from 1 to 9 February 1992. Data from two X-band Döppler radars, drop sondes, and rawinsondes were utilized in the following analysis (see Fig. 1). The study area was set up over the Sea of Japan around Tobishima Island. The two Döppler radars were placed $37 \mathrm{~km}$ apart along the coastal line. These radars were operated mostly in dual mode. Dual-Döppler radar observations were carried out at intervals of 8 minutes and each volume scan for one dual-Döppler radar observation required several minutes.

Figure 2 shows a surface weather map at 0900 JST on 9 February 1992. Hereafter, all times are expressed in Japan Standard Time (JST). This map indicates a winter monsoon condition favorable for snow cloud formation: high pressure is to the west and low pressure is to the east. The pressure contour lines were sparce over the Sea of Japan, so that the cold air outbreak from the continent was rather weak in this case.

Dual-Döppler radar and drop sonde observations of isolated snow clouds were made around 0900. The hodograph obtained over Tobishima Island at 0815 is shown in Fig. 3. The averaged velocity of the travel of the snow clouds is indicated by a cross mark. The vertical wind shear was weak and its magnitude was $\sim 3 \times 10^{-3} \mathrm{~s}^{-1}$ between the $0.07 \mathrm{~km}$ and $2.0 \mathrm{~km}$ level. This value is in the range between 0 to $4 \times 10^{-3} \mathrm{~s}^{-1}$, in which the formation of isolated convective clouds have been reported in other studies (Weisman and Klemp, 1982; Weisman and Klemp, 1984; Tabata et al., 1989; Ikawa et al., 1991). The horizontal winds relative to the cloud motion were characterized by rearward and forward flows with respect to the cloud movement at low levels and upper levels, respectively. Hereafter, the terms of rearward and forward are always used with respect to the cloud movement.

The PPI image at 0940 is shown in Fig. 4. Isolated echoes of snow clouds with a horizontal scale of several to ten kilometers were scattered over the Sea of Japan. The radar reflectivity (dBZ) was relatively weak, with the maximum of $20 \mathrm{dBZ}$. The positions of the drop sonde releases are also indicated in the figure by marks of a solid circle and triangle. The two soundings were made in and outside the cloud. The snow cloud observed by the drop sondes was considered to be in an early decaying stage because reflectivity of the snow cloud at the level of $0.3 \mathrm{~km}$ gradually decreased with time. Figure 5 shows vertical profiles of potential and equivalent potential temperatures in and outside the cloud. The air outside the cloud was convectively unstable up to the $\sim 1 \mathrm{~km}$ level. Convection would occur with some trigger of lifting. The air inside the cloud was, on the contrary, rather stable. The air in the cloud below the $0.5 \mathrm{~km}$ level was colder by $1-2 \mathrm{~K}$ than that outside the cloud. The surface equivalent potential temperature in the cloud was almost the same as in the outside air at the $\sim 1.2 \mathrm{~km}$ level. This fact suggests that the colder surface air originated from the ambient air at the $\sim 1.2 \mathrm{~km}$ level.

The convective available potential energy (CAPE) was at most $\sim 10 \mathrm{~m}^{2} \mathrm{~s}^{-2}$ and much smaller than that for deep convective cloud cases (often exceeding $2000 \mathrm{~m}^{2} \mathrm{~s}^{-2}$ ).

\section{Data processing of dual-Döppler radar ob- servations}

The retrieval of three-dimensional wind fields was carried out by the method proposed by Ray et al. (1980). At first, the collected radial data of the two radars were interpolated onto the common grids of a Cartesian coordinate system using the Cressmantype weighting function with a spherical influence volume of $0.7-\mathrm{km}$ radius. The horizontal grid spac- 


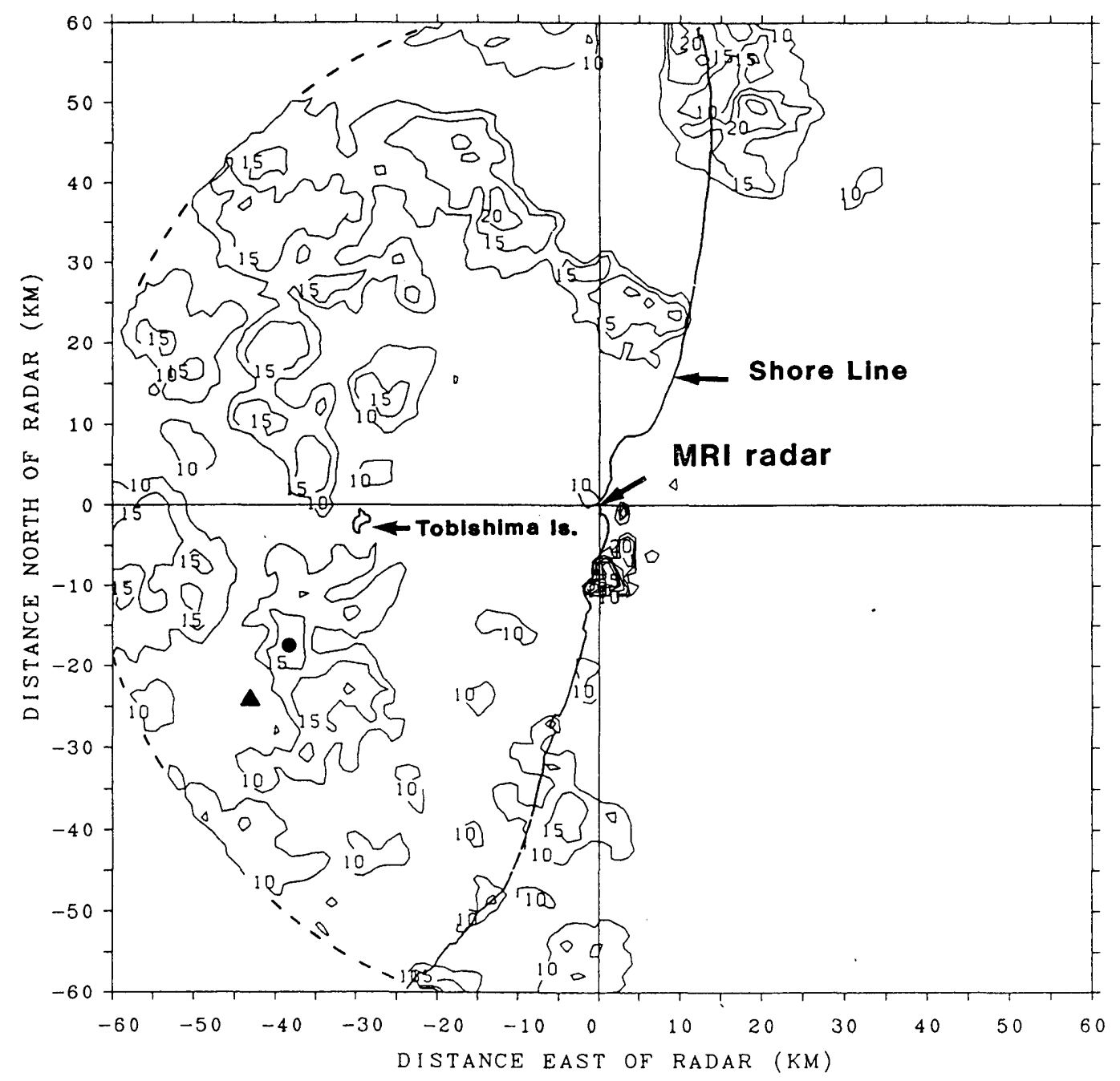

Fig. 4. PPI image of the MRI Döppler radar at 0940 at an elevation of 1.5 degrees. The positions of drop sonde releases are also indicated: a solid circle and solid triangle indicate the dropping positions in and outside the cloud, respectively. Thin solid lines indicate reflectivity contours at 5-dBZ intervals above $10 \mathrm{dBZ}$. A solid line indicates a shore line. The MRI radar is placed at the $(0,0) \mathrm{km}$ position. Dashed lines indicate the limit of the detection range of the radar.

ings were $0.7 \mathrm{~km}$ in each direction. The $\mathrm{x}$ - and $\mathrm{y}$ directions were taken toward the east and the north, respectively. In the vertical, the grid spacing was $0.3 \mathrm{~km}$ and the first analysis level was at $0.3 \mathrm{~km}$ ASL (hereafter all heights are referred to as above mean sea level).

The terminal fall velocities of hydrometeors needed in the retrieval were computed from the empirical formula for snow particles derived by Atlas et al. (1973). The error included in the terminal velocity estimates did not seriously alter the obtained wind fields because the radial components of the terminal fall velocity were small due to the low elevation angles of the scanning. The elevation angles of the PPIs in volume scans of the dual-Döppler radar observations did not exceed 20 degrees.
An advection correction scheme suggested by GalChen (1982) was also used. The velocities of the echo movement required to compensate the advection of the system were determined using the displacements of the echo patterns in the PPI images at the low elevation angles in the successive volume scans. The obtained velocities were considered as the mean velocity averaged over the echoes in the dual-processing area. The velocity components of the echo movement were 7.4 and $-1.4 \mathrm{~m} \mathrm{~s}^{-1}$ in the $\mathrm{x}$ - and $\mathrm{y}$-directions, respectively, when averaged over 8 dual-Döppler radar observations from 0956. This velocity is already indicated in Fig. 3. Each echo motion was nearly the same as the obtained one. The error included in the velocities was estimated to be $\sim \pm 1 \mathrm{~m} \mathrm{~s}^{-1}$. 
0935, 0945 JST 9 Feb. 1992

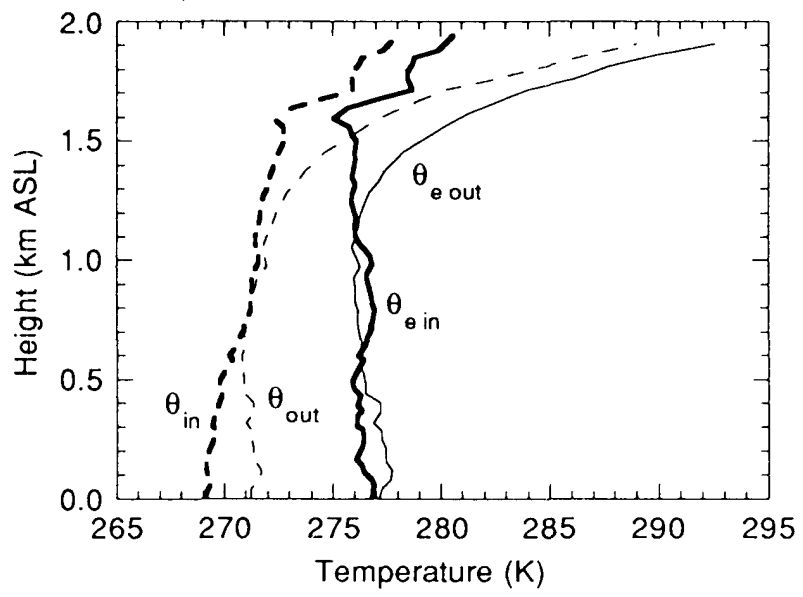

Fig. 5. Vertical profiles of potential (dashed lines) and equivalent potential (solid lines) temperatures in and outside the cloud. The bold and thin lines indicate the profiles in and outside the cloud, respectively.

Horizontal winds were not computed if the viewing angle between the two radars was less than 30 degrees or greater than 150 degrees, in order to avoid large errors in the horizontal wind estimation.

The vertical air velocities were computed by integrating upward the anelastic mass continuity equation with the assumption that vertical velocities were zero at the surface. Although it is common in dual-Döppler radar analyses that the adjustment of vertical wind fields are made by variational principles (Ray et al., 1980; Chong and Testud, 1982), no adjustments were imposed on the original wind fields in the present study. Since the integration was confined to shallow layers up to $\sim 2-\mathrm{km}$ level, the accumulation of errors in the vertical air velocities was considered to be small.

\section{Results of Dual-Döppler Radar Observa- tions}

\section{a. Evolution of the single cells}

Figure 6 shows reflectivity, horizontal divergence, and system-relative horizontal wind fields at the level of $0.3 \mathrm{~km}$ derived from dual-Döppler radar observations at 8-minute intervals from 0956. The analysis will be made for the two main cells, labeled Cell 1 and Cell 2. At 0956, Cell 1 and Cell 2 were, respectively, in their developing and decaying stages. The stages of the snow clouds were determined from the time change of reflectivity fields at the $0.3 \mathrm{~km}$ level. Since the main body of precipitation reaches the surface in the mature stage, we determined that a cell was in its mature stage when the maximum reflectivity appeared at the lowest level of CAPPI. Cell 1 appeared around 0940. Then, it developed to be mature at around 1012, reaching its maximum reflectivity of $19 \mathrm{dBZ}$. From this time, it started to decay quickly, completely disappearing by 1036 . The lifetime of Cell 1 was, therefore, about an hour. At 1012, a small echo, Cell 3, appeared upwind of Cell 1. Close examination of the CAPPIs at higher levels indicated that this cloud was not a new cell but a preexisting elevated echo, which having decayed, was reactivated. Cell 4 was a new cell, and it started to grow in the vicinity of Cell 1 at about 1020 (see Fig. 7). On the other hand, Cell 2 was always in its decaying stage in this period. Its area and reflectivity decreased with time, and it almost disappeared by 1028. Cell 2 lasted for at least 40 minutes in its decaying stage. The period of the decaying stage detected by radar was in a range of 20 to 40 minutes.

The horizontal divergence fields were also superposed in Fig. 6. Generally the system relative horizontal wind fields are characterized by convergent inflow in the southeastern flank and divergence outflow in the rear portion. However, in Cell 1 at 1020 the convergence is not seen in the southeastern flank but in the southwestern flank. It seems that a newly growing Cell 4 to the southeast of Cell 1 cut off the low-level inflow and prevented the formation of a convergence zone in the southeastern portion of Cell 1. Instead, Cell 4 grew, being fed by the southeasterly low-level inflow.

\section{b. The structures of Cell 1 and Cell 2 in the vertical cross-sections}

Figure 8 shows the vertical cross-sections of Cell 1 , in which airflow and reflectivity fields from 0956 to 1028 are depicted. These cross-sections were taken along a line $\mathrm{AA}^{\prime}$ in Fig. 6, which passed through the center of the cell. They also passed the position where a relatively large magnitude of convergence and divergence existed at the lowest level. They depict well typical airflow patterns in the cloud. The arrows are vector representations of the relative horizontal and vertical winds. In the figure, the ratio between the lengths of the reference arrows of $3 \mathrm{~m} \mathrm{~s}^{-1}$ in the horizontal and vertical directions is exactly the same as that between the lengths corresponding to $1 \mathrm{~km}$ in the horizontal and the vertical directions. This allows the wind vectors to be representative of the streamlines.

The wind fields in the cross-sections changed with time. In the developing stage at 0956 and 1004, the updrafts dominated in the whole cloud, though downdrafts were present in the very narrow region of the rearward portion. The magnitude of the updrafts was at most $2 \mathrm{~m} \mathrm{~s}^{-1}$. The updraft slightly tilted toward the opposite direction from the cloud movement. The downdraft was well collocated with a relatively large reflectivity region. In the mature stage at 1012, updrafts and downdrafts occupied al- 

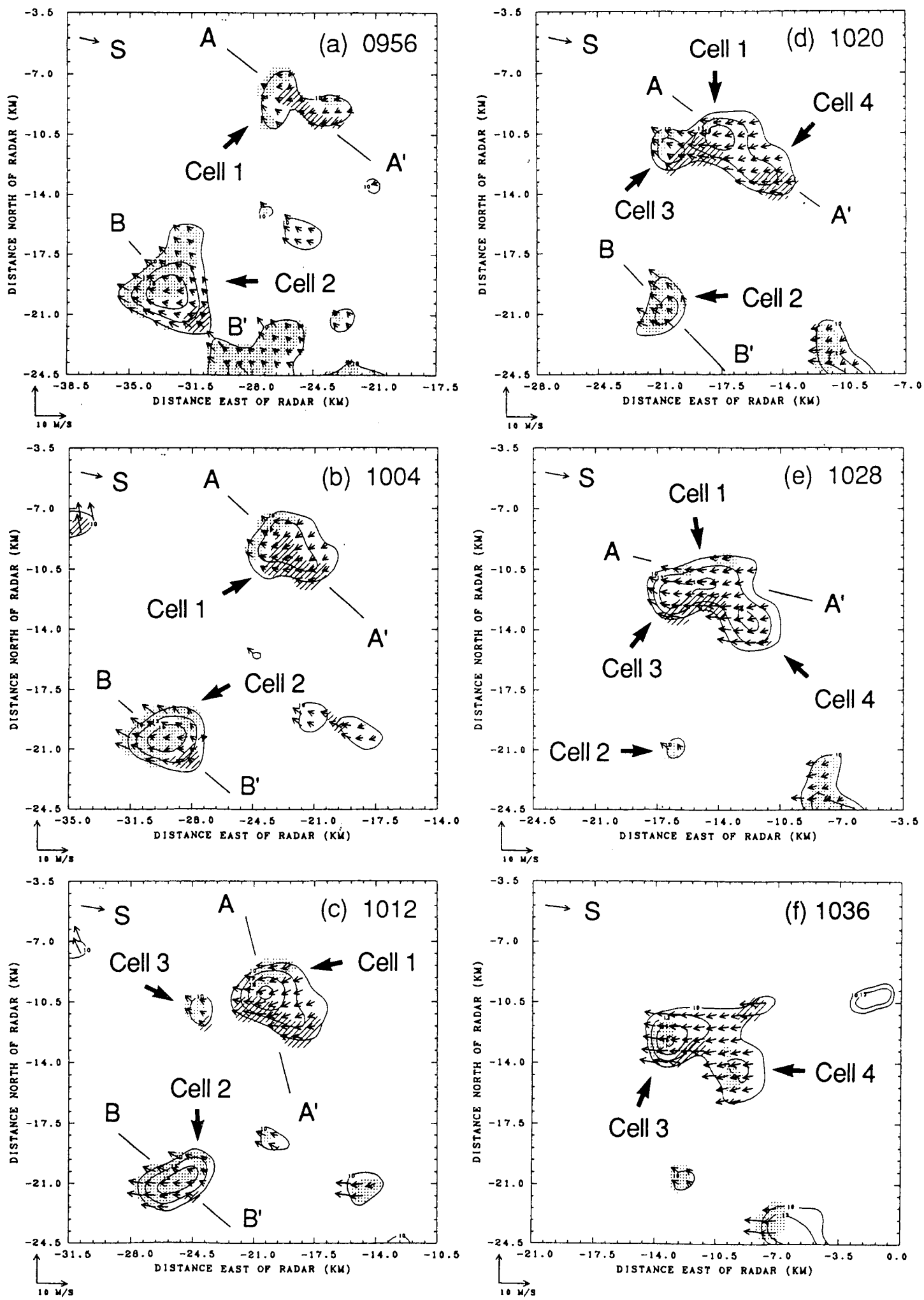

Fig. 6. The CAPPIs of 0.3-km level at 8-minute intervals, beginning from 0956 JST. The observation times are indicated in the upper right corner of each figure. The thin solid lines indicate reflectivity contours at 3-dBZ intervals starting from $10 \mathrm{dBZ}$. Horizontal divergence greater than $5 \times 10^{-4} \mathrm{~s}^{-1}$ is stippled and that smaller than $-5 \times 10^{-4} \mathrm{~s}^{-1}$ is hatched. Arrows indicate relative-winds. The reference arrows in both directions are indicated in the lower left corner in each panel. The velocity of movement of echoes is shown by an arrow labeled (s) in the upper left corner of each panel. The lines $\mathrm{AA}^{\prime}$ and $\mathrm{BB}^{\prime}$ are taken to give the vertical cross-sections shown in Figs. 8 and 10. The distances $(\mathrm{km})$ in the $\mathrm{x}$ - and $\mathrm{y}$-directions are expressed from the MRI Döppler radar site. 


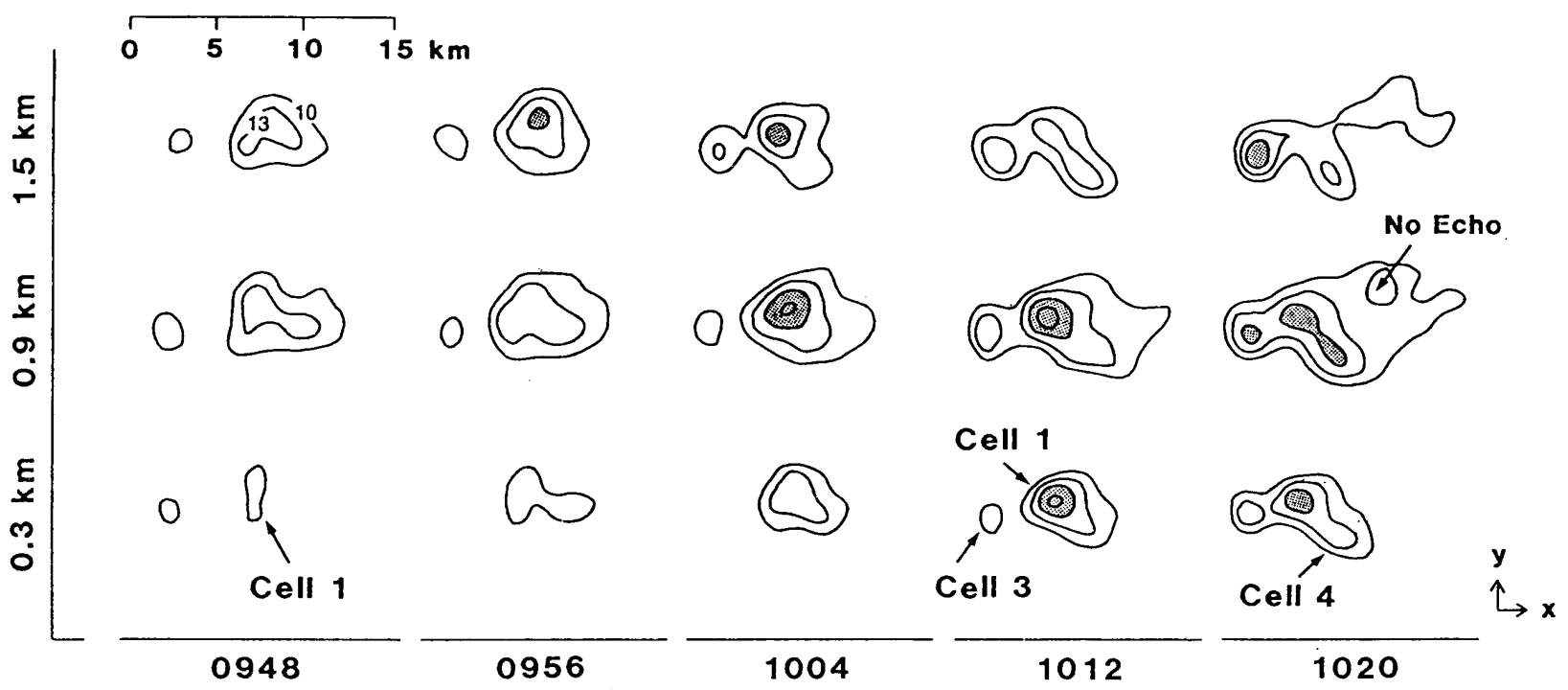

Fig. 7. Horizontal cross-sections of the reflectivity fields of Cells 1,3 , and 4 at the levels of $0.3,0.9$, and $1.5 \mathrm{~km}$. The reflectivity contour interval is $3 \mathrm{dBZ}$, and the areas with reflectivity exceeding $16 \mathrm{dBZ}$ are stippled. The horizontal scale is show in the upper-left corner, and the scales in $\mathrm{x}$ - (eastward) and $y$ - (northward) directions are the same.

most comparable areas in the cloud. The magnitude of the updrafts was nearly the same as in developing stage. The slight tilting of the updraft toward the opposite direction was also seen, while the degree of tilting did not change much from that in developing stage. The downdrafts below the $1.2-\mathrm{km}$ level at $x=-20.3 \mathrm{~km}$ and $y=-9.7 \mathrm{~km}$ had horizontal wind components toward the cloud motion. At the lowest level, however, these components were not significant any more, which was due in part to the underestimation of the wind velocities because the measured Döppler velocities at the lowest elevation angle of $0.5^{\circ}$ were often contaminated by the sea clutter. In the decaying stage, the area of downdrafts increased with time. By 1028, downdrafts occupied almost the whole cloud. However, slight updrafts remained in the upper forward portion of the cloud. In this stage, the magnitude of the updrafts gradually weakened to be less than $1 \mathrm{~m} \mathrm{~s}^{-1}$. The above estimates of the updraft in the three stages seem reasonable as compared with the observed values of several meters per second in other types of snow clouds over the Sea of Japan (Sakakibara et al., 1988; Ishihara et al., 1989; Satoh et al., 1992; Yamada et al., 1992).

The time variation of the reflectivity fields in the cross-sections are also depicted in the same figure, suggesting a formation process for the main body of precipitation in the cloud. In the developing stage, a reflectivity contour of $16 \mathrm{dBZ}$ appeared around the $1.2-\mathrm{km}$ level in the rearward portion at 0956 . This suggests that snow particles was growing in the upper portion of the updraft region. Since the reflectivity at the surface was weak, being 10-13 dBZ, precipitation at the surface was very weak. The area encircled by the contour extended downward at 1004 , suggesting that the region of relatively strong precipitation intensity had started to descend. Since the reflectivity at the lowest level remained nearly the same as at 0956, precipitation at the surface was still very weak. In the mature stage at 1012 , the contour reached the $0.3 \mathrm{~km}$ level, and the contour of $19 \mathrm{dBZ}$ appeared between the levels of 0.3 and $0.6 \mathrm{~km}$. Probably, the main body of precipitation reached the surface and precipitation at the surface became relatively intense. In the decaying stage at 1028 , the contour of $16 \mathrm{dBZ}$ disappeared, and the maximum reflectivity in the cloud decreased to 13 dBZ. Precipitation at the surface also weakened.

Figure 9 shows time variations of vertical profiles of maximum updrafts at each level in the crosssections depicted in Fig. 8. The magnitude of the updraft is one of the indices of cloud activity. The profiles are presented for the five successive crosssections from 0956 to 1028 . In making these profiles, the updrafts at the lateral boundaries were excluded because they were considered to be contaminated by relatively large errors. As seen from Fig. 9, a relatively large updraft was found in the upper portion of the cloud. From developing (at 0956 and 1004) to mature stages (at 1012), the magnitude of the updraft gradually increased at all levels. The maximum updraft of $1.3 \mathrm{~m} \mathrm{~s}^{-1}$ at the level of $1.5 \mathrm{~km}$ was found at 1012 , in the mature stage. In the decaying stage (from 1020 to 1028), the magnitudes of the updrafts at all levels were considerably smaller compared with the values in the developing and mature stages. Suppression of the updraft was clear at the 
(a) 0956

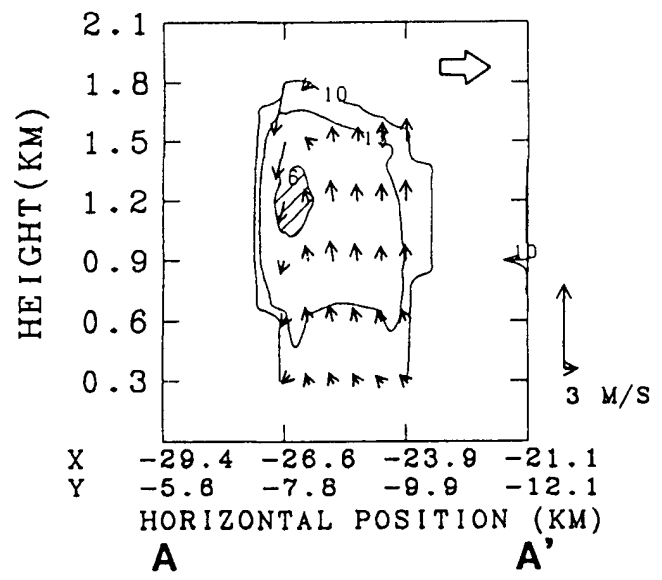

(b) 1004

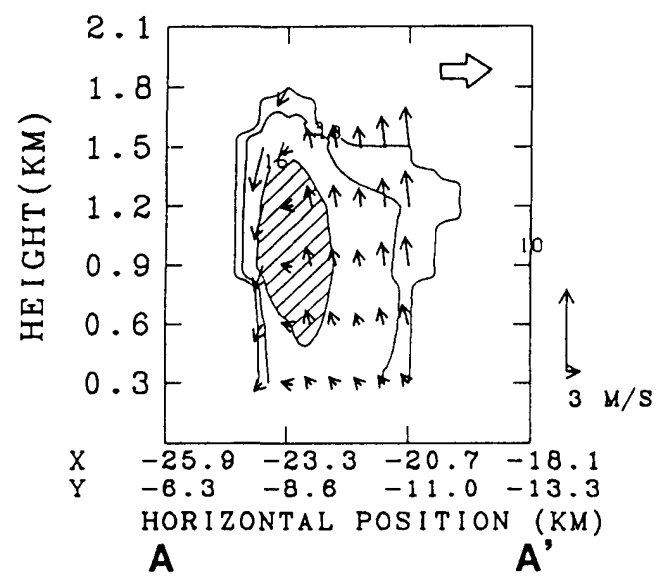

(c) 1012

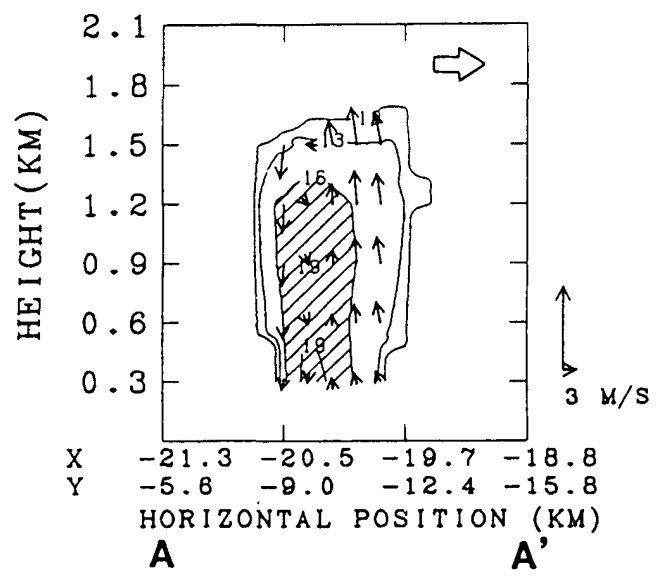

(d) 1020

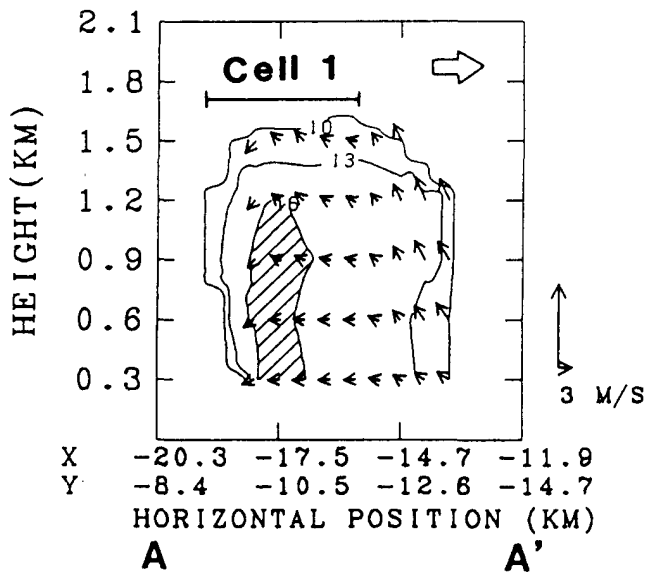

(e) 1028

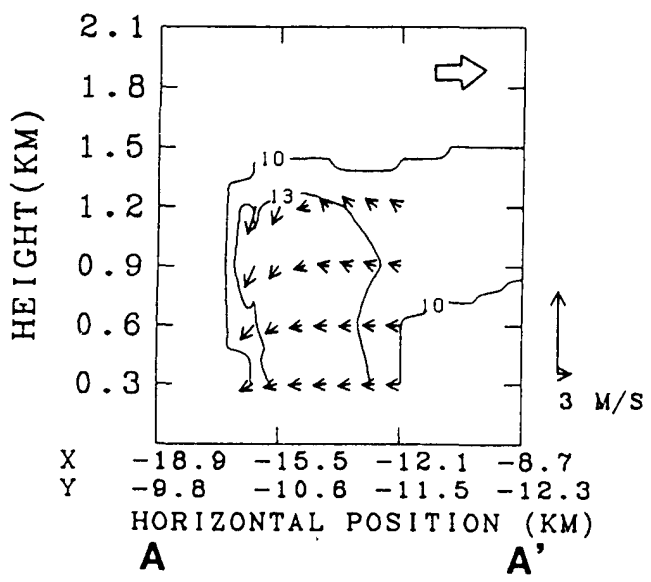

Fig. 8. Vertical cross-sections along the line $\mathrm{AA}^{\prime}$ in Fig. 6. Arrows in the figures are composites of relative wind and vertical air velocities projected onto the cross sections. Thin solid lines are reflectivity contours at $3-\mathrm{dBZ}$ intervals above $10 \mathrm{dBZ}$. The regions with reflectivity greater than 16 $\mathrm{dBZ}$ are hatched. The length of the line $\mathrm{AA}^{\prime}$ is $10.5 \mathrm{~km}$. The reference arrows of $3 \mathrm{~m} \mathrm{~s}^{-1}$ in the horizontal and vertical directions are shown in the right-bottom portion. System motion is indicated by an open arrow in the upper-right portion of each frame. The values of $\mathrm{x}$ and $\mathrm{y}$ on the bottom of each frame indicate the horizontal positions along the cross-section. 
9 Feb. 1992

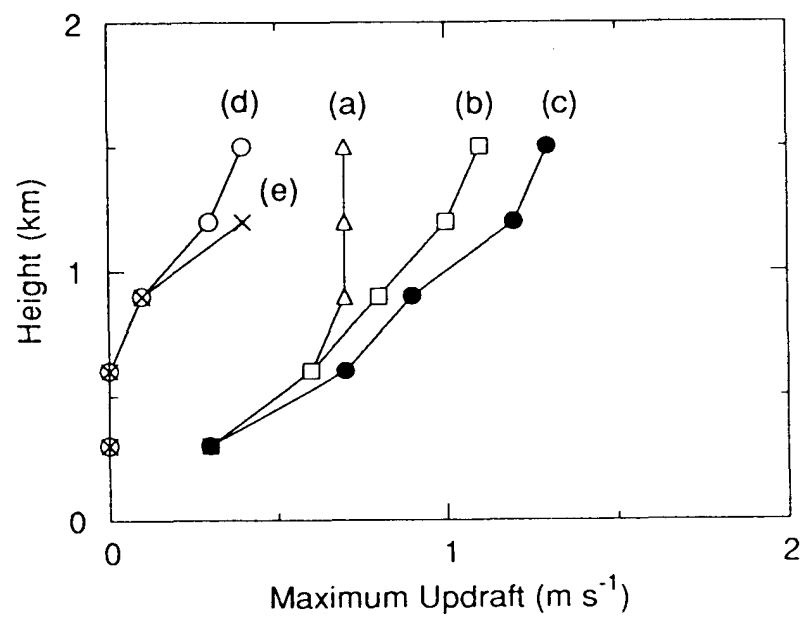

Fig. 9. Time variations of vertical profiles of maximum updraft observed in each cross-section depicted in Fig. 8. The profiles labeled (a), (b), (c), (d), and (e) are, respectively, at 0956, 1004, 1012, 1020, and 1028 JST.

lower levels. At the lower levels of 0.3 and $0.6 \mathrm{~km}$, the updraft was no longer present, while weak ones still remained in the upper portions of the cloud with a magnitude of $0.5 \mathrm{~m} \mathrm{~s}^{-1}$. The profile at 1028 shows similar features to that at 1020 , though the updraft at the $1.5-\mathrm{km}$ level was not observed because of the decrease in echo top height. Ikawa et al. (1991) obtained a similar time tendency for the updraft in a numerical simulation of an isolated snow cloud, though the updraft attained its maximum in developing stage, not in mature stage.

Figure 10 shows vertical cross-sections of Cell 2 along a line $\mathrm{BB}^{\prime}$ in Fig. 6. The airflow structures and reflectivity fields are indicated. The wind arrows are drawn in the same manner as in Fig. 8. The winds around the lateral boundaries involved some errors so that they should be interpreted in a qualitative way. The flow fields were quite similar to that in Cell 1: the updraft and the downdraft were situated in the forward and rearward portions. As Cell 2 was always in the decaying stage during this whole period, downdrafts dominated in Cell 2, with only slight area of updrafts. The updrafts were gradually replaced by the downdrafts and, by 1020 , the updrafts disappeared from the cloud. The maximum reflectivity and radar echo area of Cell 2 also gradually decreased with time.

\section{c. Horizontal divergence fields in the vertical cross- sections}

Figure 11 shows vertical cross-sections of horizontal divergence fields in Cell 1 in the developing (a), mature (b), and decaying (c) stages. These crosssections were taken along the same line as in Fig. 6 .
On the whole, regardless of the stages, the convergence and divergence zones were situated in the forward and rearward portion of the cloud, respectively. However, time change in the convergence fields was evident. In the developing and mature stages, the magnitude of convergence increased with decreasing height and attained $1 \times 10^{-3} \mathrm{~s}^{-1}$ at low levels. On the other hand, in the decaying stage, convergence was no longer present at the level of $0.3 \mathrm{~km}$, while weak convergence of magnitude of $5 \times 10^{-4} \mathrm{~s}^{-1}$ still remained in the upper portion.

\section{Discussion}

The dominance of updraft and downdraft regions in the snow clouds in the three stages and the time tendency of the updraft are quite similar to those in a summertime isolated convective cloud derived from dual-Döppler radar observations (Tabata et al., 1989) though the spatial scales, especially the vertical extent of $\sim 2 \mathrm{~km}$, of the snow clouds are much smaller than those of the summertime convective cloud with the echo top height of $\sim 6 \mathrm{~km}$. For both cases, the maximum updrafts were observed in the mature stage. As for the lifetime, however, the summertime convective cloud persisted for more than 2 hours, while the snow cloud persisted for only $\sim 1$ hour. Tabata et al. attributed the much longer lifetime to the distinct separation between updraft and downdraft regions in the cloud due to the increase in the tilting of the main updraft with time from the developing to the mature stages. However, in the present case, the tilting of the updraft did not change so much with time between the two stages.

The lifetime of $\sim 1$ hour of the isolated snow cloud is relatively long among isolated convective clouds. According to the study by Bennetts et al. (1986), the typical lifetime of a single cell is $3 / 4$ to $\sim 1$ hour under the presence of vertical shear and $1 / 2$ hour under no vertical shear. Since the vertical shear results in a separation between updraft and downdraft regions in a cloud, the downdraft due to the mass loading would not immediately suppress the updraft. As a consequence, clouds in a vertical shear condition could persist longer than those in no vertical shear. This was the case in the isolated snow cloud. In addition, there seem to be two possible factors contributing to their relatively long persistence. One factor is the effect of upshear-tilting updraft on cloud lifetime. The flow structures depicted in Figs. 8 and 10 bore resemblance to those in the "long-lasting" clouds formed in a vertical shear with a jet at a certain level, which were discussed by Takeda (1971). The vertical profile of the horizontal winds parallel to the cloud motion (shown in Fig. 12), which is also considered to be an approximate profile parallel to the vertical cross-sections shown in Figs. 8 and 10, indicates that the relative winds below and above the $\sim 1.1-\mathrm{km}$ level were, re- 
(a) 0956

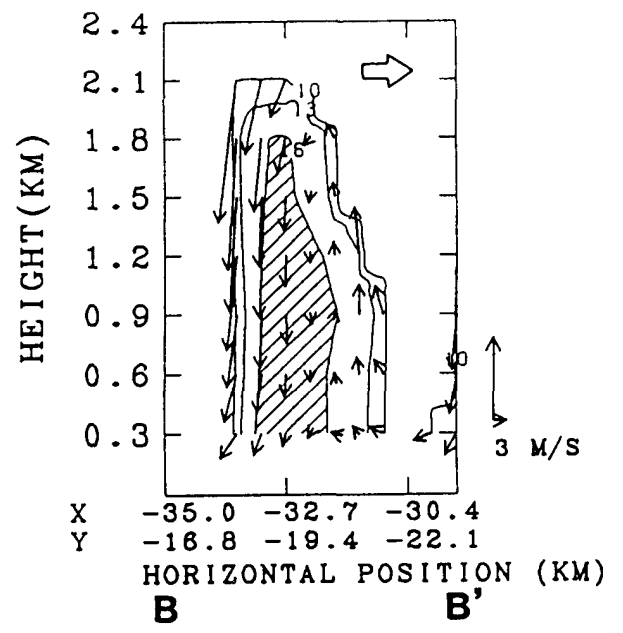

(b) 1004

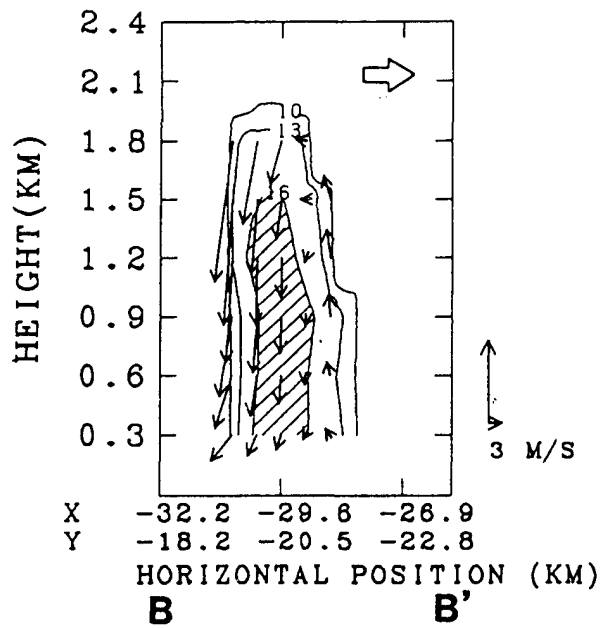

(c) 1012

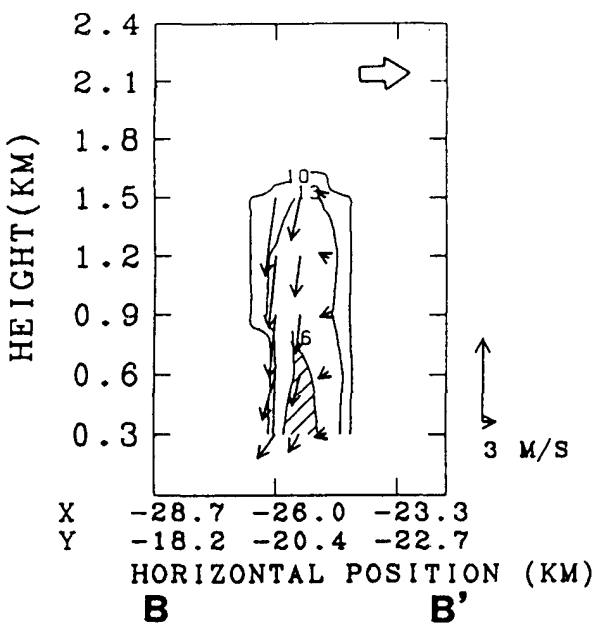

(d) 1020

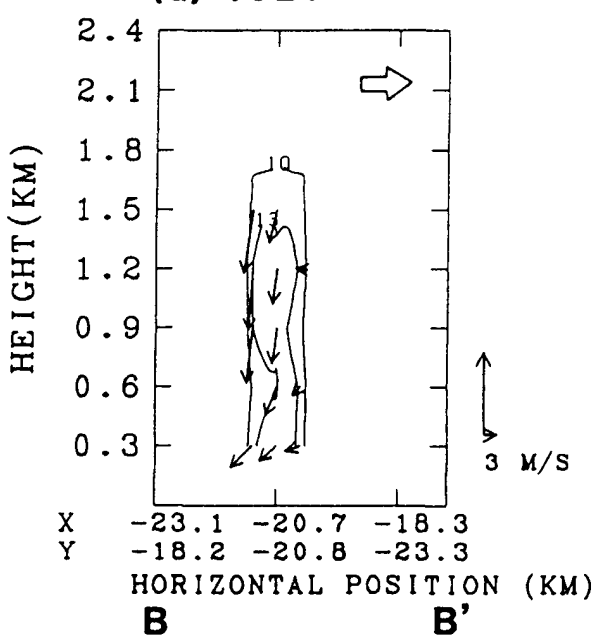

Fig. 10. The same as Fig. 8, except for cross-sections along the line $\mathrm{BB}^{\prime}$ in Fig. 6 . The length of the line $\mathrm{BB}^{\prime}$ is $8.4 \mathrm{~km}$.

spectively, rearward and forward with a jet at the level of $0.9 \mathrm{~km}$. This vertical wind shear would produce the upshear-tilting updraft and consequently maintain the snow cloud for a longer time. The other factor is the fall velocity of precipitation particles. Since the fall velocities of snow particles are in general smaller than those of rain drops, snow particles can stay longer in clouds than rain drops. Consequently, the isolated snow cloud would last longer compared with an isolated rain-producing convective cloud of equal size.

In a cloud, the low-level convergence is considered to occur between the inflow of ambient air and the precipitation-induced cold air. As seen from Fig. 12, the low-level convergence between the cold air and the ambient low-level air preferred to occur in the forward portion rather than in the rearward portion because the cold air originating from the level of $1.2 \mathrm{~km}$ had larger horizontal velocities than did the ambient air. This is consistent with the results of the observations, as shown in Figs. 11a and 11b. More precisely speaking, the positions of convergence at the level of $0.3 \mathrm{~km}$ were situated in the southeastern portion of the cloud but not in the eastern portion. This is explained by the wind shear depicted in Fig. 3. The downdraft originating from the ambient air at the $1.2-\mathrm{km}$ level had a much more northerly component. However, when there exist some cells nearby, the low-level convergence does not always appear in the expected position; e.g., the case of Cell 1 at 1020 described in Section 4a. In such a situation, interaction among the cells becomes important, though the mechanisms of the interaction still remain unknown.

The wind profile depicted in Fig. 12 also suggests that a new cell tends to appear ahead of a 'parent' cell due to the convergence between the spreading cold air ahead of the cloud and the ambient unstable air. The mechanism of the low-level convergence is the same as that in the cloud described in the pre- 


\section{(a) 0956}

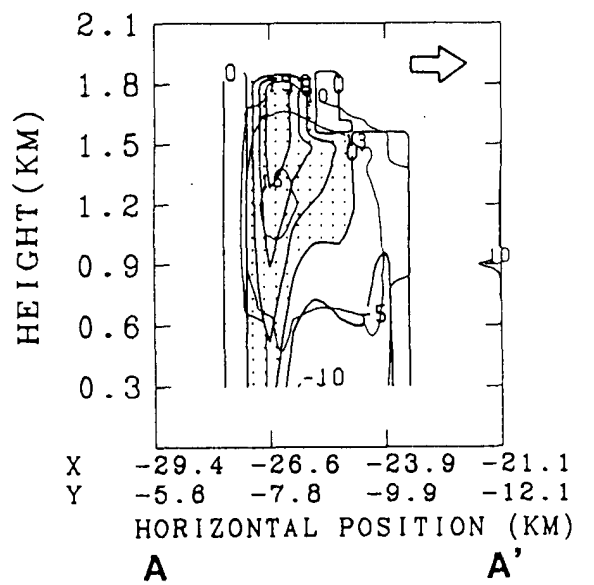

(b) 1012

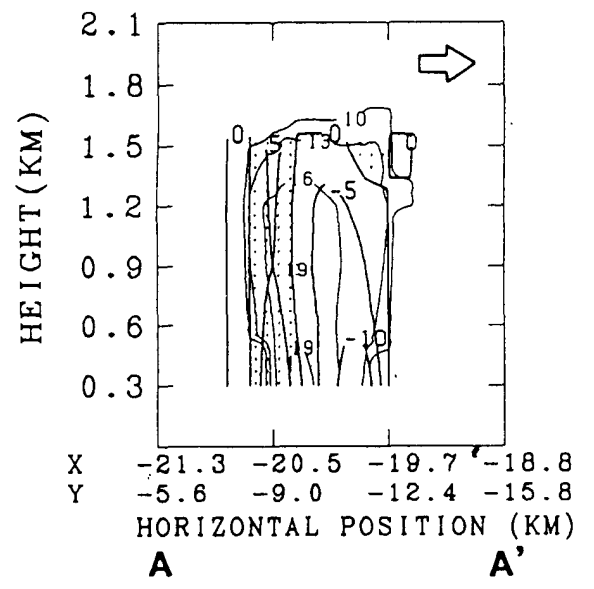

(c) 1028

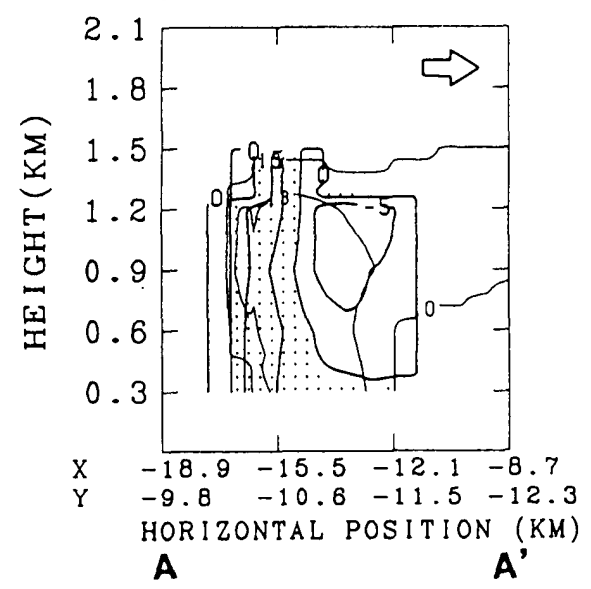

Fig. 11. Vertical cross-sections of horizontal divergence of a developing cloud (a), mature cloud (b) and decaying cloud (c). Areas of horizontal divergence are indicated by stippling. The contour interval of horizontal divergence is $5 \times 10^{-4} \mathrm{~s}^{-1}$. Thin solid lines indicate reflectivity contours at 3-dBZ intervals starting from 10 $\mathrm{dBZ}$. System motion is indicated by an open arrow in the right-upper portion in each frame.

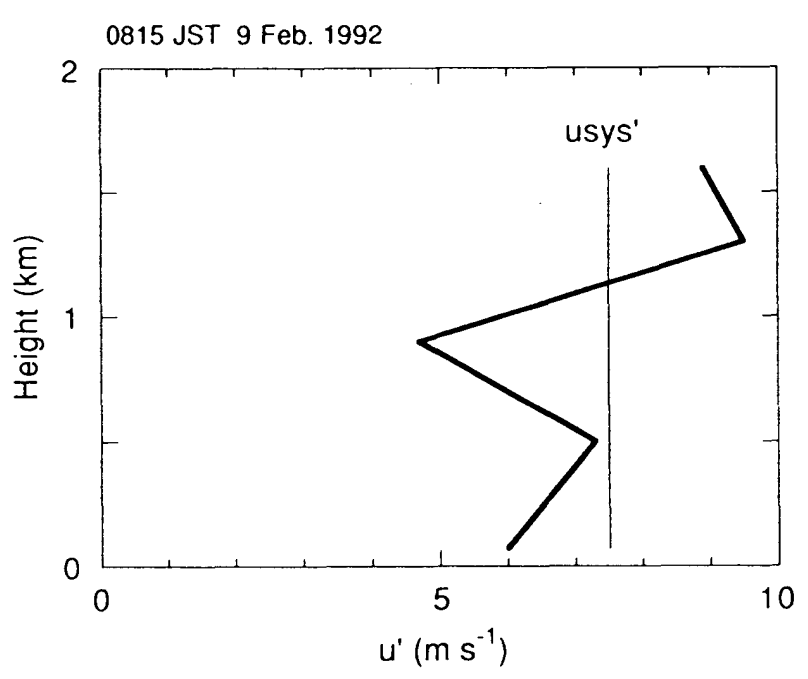

Fig. 12. Vertical profile of the horizontal wind component in the vertical plane parallel to the cloud motion (bold line). The thin line labeled 'usys' indicates the cloud motion of $7.5 \mathrm{~m} \mathrm{~s}^{-1}$.

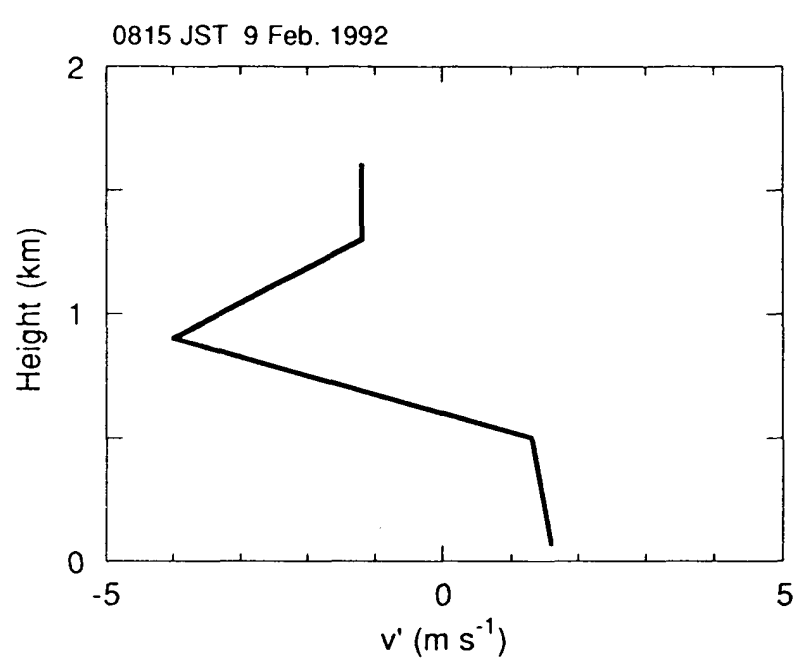

Fig. 13. Vertical profile of the horizontal wind component in the vertical plane perpendicular to the cloud motion. In this profile, the cloud motion is $0 \mathrm{~m} \mathrm{~s}^{-1}$.

vious paragraph. This convergence may have triggered the formation of Cell 4 .

On the other hand, reactivation of Cell 3 is not sufficiently explained by the wind profile in Fig. 12 because weak divergence is expected behind Cell 1 . However, if the vertical profile of horizontal wind components normal to the cloud motion is taken into account (Fig. 13), a convergence between the spreading cold air and the ambient low-level unstable air is expected there. The wind components below and above the $0.6 \mathrm{~km}$ level were positive and negative, respectively, where the positive values indicate the wind components toward the north. Since 
(a) Developing

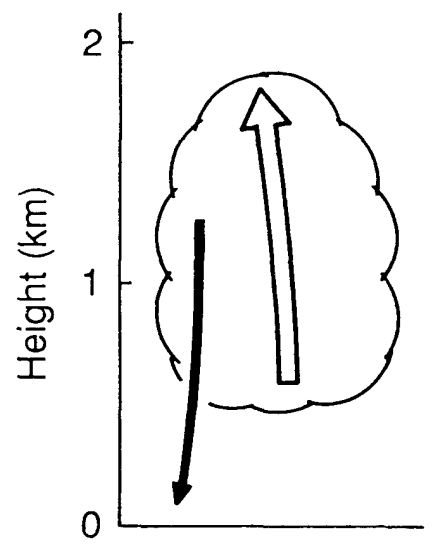

(b) Mature

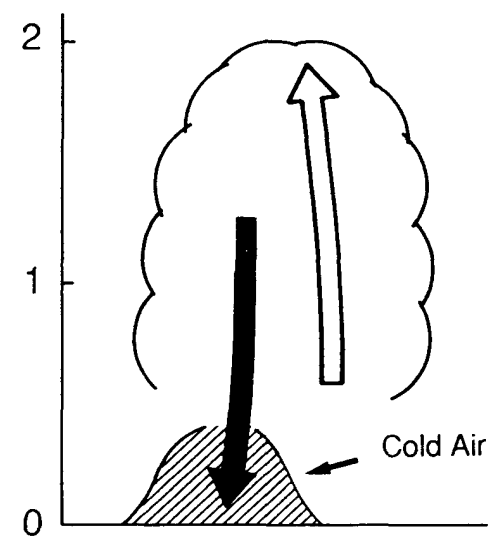

(c) Decaying

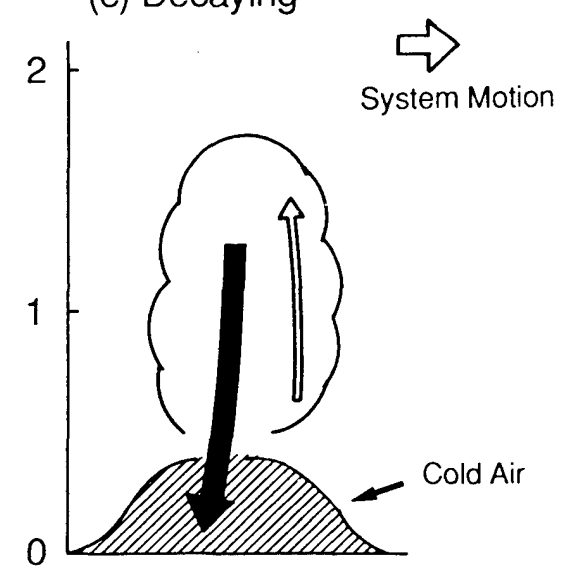

Fig. 14. Conceptual model of airflow structures in an isolated snow cloud in the developing, mature, and decaying stages.

the spreading cold air originated from the $\sim 1.2-\mathrm{km}$ level, where the northerly component was stronger than at low levels, a low-level convergence between the ambient unstable air and the spreading cold air would occur. This convergence seems to be important to the reactivation of Cell 3 .

\section{Conclusions}

The time variations of the airflow structures in isolated snow clouds have been studied by means of dual-Döppler radar and supplementary soundings. These clouds were formed in the environment of a weak vertical wind shear. The lifetime of the clouds was about 1 hour.

The results of the observations indicated that the airflow structures in the clouds changed with time. Based on the results of the observations, a conceptual model is proposed concerning the airflow structures of isolated snow cloud in the developing, mature, and decaying stages (Fig. 14). The arrows indicate system-relative airflows. In the developing stage, the updraft occupied almost the whole cloud, though a slight downdraft was observed in the rearward portion. The magnitude of the updraft was at the most $2 \mathrm{~m} \mathrm{~s}^{-1}$. The precipitation at the surface was very weak because the precipitation particles were growing in the upper part of the updraft region. In the mature stage, the updraft and the downdraft regions were comparable in area. The maximum updraft was observed in this stage. The main body of precipitation reached the surface. The downdrafts associated with mass loading of precipitation particles developed next to the updraft because of the weak vertical shear. As a result, the updraft tended to be gradually replaced by the downdraft. The downdraft spread near the surface as a cold outflow. The cold air may have triggered new cells or reactivated the preexisting cells through the interaction with the ambient low-level air. The newly developing cells were still isolated ones because the 'parent' cells tended to dissipate over a short period. In the decaying stage, a downdraft dominated in the greater part of the clouds with a slight updraft in the upper portions. The remaining updraft was quickly replaced by the downdraft. The surface precipitation was also very weak. The magnitude of the updraft was smaller than in the developing and mature stages.

Since the vertical wind shear brought about the slight separation between the updraft and downdraft regions and the vertical wind profile may have been favorable for the formation of an upshear-tilting updraft, the isolated snow cloud could persist for a relatively long time. Precipitation in the form of snow particles may also contribute to the relatively long persistence of the isolated snow cloud. However, it did not take a long time for the downdraft to suppress the updraft because of insufficient separation between them.

\section{Acknowledgments}

The authors would like to thank gratefully all members of the Third Research Laboratory of the Typhoon Department of the Meteorological Research Institute for their support in making the observations. Special recognition must be given to Dr. Ishihara for providing us with useful programs for dual-Döppler radar analyses. We are also grateful to Dr. Maki and Mr. Nakai of the National Institute for Earth Science and Disaster Prevention of the Science and Technology Agency for assisting us in the observations. The authors also wish to thank Professor T. Harimaya, Hokkaido University, and two anonymous reviewers for constructive comments.

The field experiments were conducted as a part of the research project "Study on Precipitation Formation in Snow Clouds and the Feasibility of Snow 
Cloud Modification by Seeding" financially supported by Science and Technology Agency of Japan.

\section{References}

Atlas, D., R.C. Srivastava, and R.S. Sekhon, 1973: Döppler radar characteristics of precipitation at vertical incidence. Rev. Geophys. Space Phys., 11, 1-35.

Bennetts, D.A., E. McCallum and J.R. Grant, 1986: Cumulonimbus clouds: an introductory review. Meteor. Mag., 115, 242-256.

Chong, M. and J. Testud, 1983: Three-dimensional wind field analysis from dual-Döppler radar data. Part III : The boundary condition: An optimum determination based on a variational concept. J. Climate Appl. Meteor., 22, 1227-1241.

Gal-Chen, T., 1982: Errors in fixed and moving frame of references: Applications for conventional and Döppler radar analysis. J. Atmos. Sci., 39, 22792300.

Ikawa, M., H. Mizuno, T. Matsuo, M. Murakami, Y. Yamada, and K. Saito, 1991: Numerical modeling of the convective snow cloud over the Sea of Japan. - Precipitation mechanism and sensitivity. J. Meteor. Soc. Japan, 69, 641-667.

Ishihara, M., H. Sakakibara and Z. Yanagisawa, 1989: Döppler radar analysis of the structure of mesoscale snow bands developed between the winter monsoon and the land breeze. J. Meteor. Soc. Japan, 67, 503520.

Kelly, R.D., 1982: A single Döppler radar study of horizontal-roll convection in a lake effect snow storm. J. Atmos. Sci., 39, 1521-1531.

Kelly, R.D., 1984: Horizontal roll and boundary-layer interrelationships observed over Lake Michigan, $J$. Atmos. Sci., 41, 1816-1826.

Kristovich, D.A.R., 1990: Aircraft and radar observations of the three-dimensional flow fields of boundary layer rolls. Preprints, Conference on Cloud Physics, San Francisco, Amer. Meteor. Soc., 706-711.

Murakami, M., T. Matsuo, H. Mizuno, and Y. Yamada,
1994: Mesoscale and microscale structures of snow clouds over the Sea of Japan. Part I: Microphysics of short-lived snow clouds. submitted to J. Meteor. Soc. Japan.

Ray, P.S., C.L. Ziegler, W. Bumgarner and R.J. Serafin, 1980: Single- and multiple-Döppler radar observations of tornadic storms. Mon. Wea. Rev., 108, $1607-1625$.

Sakakibara, H., M. Ishihara and Z. Yanagisawa, 1988: Classification of mesoscale snowfall systems observed in western Hokuriku during a heavy snowfall period in January 1984. J. Meteor. Soc. Japan, 66, 193-199.

Sakakibara, H., M. Ishihara and Z. Yanagisawa, 1988: Squall line like convective snow bands over the Sea of Japan. J. Meteor. Soc. Japan, 66, 937-953.

Satoh, S., Y. Fujiyoshi, G. Wakahama, R. Shirooka and H. Uyeda, 1992: Dual-Döppler radar observation of convergence band cloud. Proceedings, 11th International Conference on Clouds and Precipitation, Montreal, Canada, 628-631.

Tabata, A., S. Nakazawa, Y. Yasutomi, H. Sakakibara, M. Ishihara, and K. Akaeda, 1989: The structure of a long-lasting single cell convective cloud. Tenki, 36, 25-33. (in Japanese).

Takeda, T., 1971: Numerical simulation of a precipitating convective cloud: The formation of a "longlasting" cloud. J. Atmos. Sci., 28, 350-376.

Weisman, M.L. and J.B. Klemp, 1982: The dependence of numerically simulated convective storms on vertical wind shear and buoyancy. Mon. Wea. Rev., 110, 504-520.

Weisman, M.L. and J.B. Klemp, 1984: The structure and classification of numerically simulated convective storms in directionally varying wind shears. Mon. Wea. Rev., 112, 2479-2498.

Yamada, Y., T. Matsuo, M. Murakami and H. Mizuno, 1992: Mesoscale structure of snow bands over the Sea of Japan. Proceedings, 11th International Conference on Clouds and Precipitation, Montreal, Canada, 605-608. 


\section{日本海降雪量のメソスケール及びマイクロスケールの構造 第二部：デュアルドップラーレーダー解析に基づく孤立型}

降雪雲の気流構造の時間変化

一事例解析一

\section{山田芳則・松尾敬世・村上正隆・水野 量 \\ (気象研究所) \\ 岩波 越}

（長岡雪水防災実験研究所）

日本海上に出現した孤立型降雪雲の気流構造の時間変化を明らかにするために、デュアルドップラーレー ダー観測を行った。同時に、雲内外の気象場を把握するために、ドロップゾンデとレーウィンゾンデによ る観測も行った。

孤立型降雪雲は寒気の吹き出しの後半に出現し、その寿命は約 1 時間であった。これらの降雪雲は、鉛 直シアーの弱い不安定成層内に発生したものであることがゾンデ観測からわかった。雲内の気流構造は時 間とともに変化した。発達期では、上昇流が雲内のほほ全領域を占めており、わずかに下降流が存在した。 成熟期では、上昇流と下降流の占める領域の大きさはほほ同じであった。衰弱期になると下降流が雲内の 大部分を占めるようになった。上昇流、下降流は、雲の進行方向からみて、それぞれ、前方、後方に存在し ていた。上昇流の大きさは、発達期と成熟期では高々 $2 \mathrm{~m} \mathrm{~s}^{-1}$ 、衰弱期ではそれよりも小さい值であった。 解析結果に基づき、雲の消長に伴う気流構造の变化について概念モデルを提案した。 